\title{
Down's Syndrome: Chromosome Analysis in 321 Cases in Japan
}

\author{
MAKOTO HIGURASHI,* ICHIRO MATSUI, YASUO NAKAGOME†, and \\ MASUYOSHI NAGANUMA
}

From Department of Pediatrics, University of Tokyo, Tokyo, Fapan

The present study on Down's syndrome was undertaken to evaluate the frequency of trisomy and translocation among those affected, the proportion of sporadic and inherited rearrangements in families in which translocations were present, and the proportion of translocated chromosomes identified by means of autoradiography.

\section{Materials and Methods}

In the past 7 years we have carried out chromosomal analysis on 950 patients with congenital malformations, mental retardation, sex abnormalities, and dwarfism. The total included 321 cases of Down's syndrome. The cases were divided into two groups according to maternal age at birth of affected child: younger than 30 years, and 30 years or older. They were further classified into 5yearly subgroups.

Peripheral blood (Moorhead et al., 1960) or fibroblast culture (Harnden and Brunton, 1965) techniques were used to establish the chromosome constitution of all

Received May 28, 1969.

* All correspondence to M.H. at Department of Pathology, The Research Institute, The Hospital for Sick Children, 555 University Avenue, Toronto 2, Ontario, Canada.

t Present Address: Department of Human Genetics, University of Michigan, U.S.A. affected individuals, and whenever possible of the parents of all children found to have a translocation; the translocated chromosomes were identified by labelling pattern with tritiated thymidine (Higurashi et al., 1967).

\section{Results}

The over-all findings are shown in Table I. Of 321 patients, $307(95.6 \%)$ had the standard type of G21-trisomy, including 7 mosaics. Translocations were observed in $14(4.4 \%)$ and were more frequent in younger maternal age-groups: $7 \cdot 1 \%$ of the affected children born to mothers younger than 30 years of age had a translocation, compared with about $1.3 \%$ in the older maternal age-group. Eleven of these translocations were D/G21 translocations and three were G/G21 translocations.

Table II shows the proportions of inherited and sporadic translocation in these 14 cases. The term 'sporadic' indicates that the parents of the affected child had normal karyotypes, 'inherited' means that one of the parents was a translocation carrier, and 'unknown' indicates that the chromosomal examinations of parents could not be done.

In order to identify the translocated and extra chromosome, an autoradiographic method was used

TABLE I

CHROMOSOME FINDINGS IN PATIENTS WITH DOWN'S SYNDROME

\begin{tabular}{|c|c|c|c|c|c|c|}
\hline \multirow{2}{*}{$\begin{array}{l}\text { Maternal } \\
\text { Age (yr.) }\end{array}$} & \multirow{2}{*}{$\begin{array}{l}\text { No. of } \\
\text { Patients }\end{array}$} & \multirow{2}{*}{$\begin{array}{c}\text { Regular } \\
\text { Trisomy } \\
\text { and } \\
\text { Mosaicism }\end{array}$} & \multicolumn{3}{|c|}{$\begin{array}{c}\text { Translocated } \\
\text { Down's Syndrome }\end{array}$} & \multirow{2}{*}{$\begin{array}{c}\text { Translocation } \\
(\%)\end{array}$} \\
\hline & & & $D / G$ & G/G & Total & \\
\hline $\begin{aligned}<30 \\
15-19 \\
20-24 \\
25-29 \\
\geq 30\end{aligned}$ & $\begin{array}{rr}170 \quad 9 \\
& 89 \\
& 72 \\
151\end{array}$ & $\begin{array}{r}9(0) \\
81(2) \\
68(3)\end{array}$ & $\begin{array}{l}0 \\
7 \\
3\end{array}$ & $\begin{array}{l}0 \\
1 \\
1\end{array}$ & $\begin{array}{l}0 \\
8 \\
4\end{array}$ & $7 \cdot 1$ \\
\hline $\begin{array}{r}30-34 \\
35-39 \\
40-44\end{array}$ & $\begin{array}{r}103 \\
45 \\
3\end{array}$ & $\begin{array}{r}101(1) \\
45(1) \\
3(0)\end{array}$ & $\begin{array}{l}1 \\
0 \\
0\end{array}$ & $\begin{array}{l}1 \\
0 \\
0\end{array}$ & $\begin{array}{l}2 \\
0\end{array}$ & $1 \cdot 3$ \\
\hline Total & 321 & $307(7)$ & 11 & 3 & 14 & $4 \cdot 4$ \\
\hline
\end{tabular}


TABLE II

FREQUENCY AND PROPORTIONS OF INHERITED AND SPORADIC TRANSLOCATION

\begin{tabular}{c|c|c|c|c|c|c}
\hline $\begin{array}{c}\text { Maternal } \\
\text { Age-group } \\
\text { (yr.) }\end{array}$ & \multicolumn{3}{|c|}{ D/G Translocation } & \multicolumn{3}{c}{ G/G Translocation } \\
\cline { 2 - 6 } \cline { 5 - 6 } & Sporadic & Inherited & Unknown & Sporadic & Inherited & Unknown \\
\hline $15-19$ & 0 & 0 & 0 & 0 & 0 & 0 \\
$20-24$ & 2 & 2 & 3 & 0 & 1 & 0 \\
$25-29$ & 1 & 2 & 0 & 0 & 0 & 1 \\
$30-34$ & 0 & 0 & 1 & 1 & 0 & 0 \\
$35-39$ & 0 & 0 & 0 & 0 & 0 & 0 \\
$40-44$ & 0 & 0 & 0 & 0 & 0 & 0 \\
\hline Total & 3 & 4 & 4 & 1 & 1 & 1 \\
\hline
\end{tabular}

(Higurashi et al., 1967). To obtain the labelling patterns of each chromosome, 104 metaphase plates from five normal individuals were studied. Only mitotic figures with more than $\mathbf{8 0}$ grains were selected for analysis. For quantitative analysis of grain count the mean density of the grains over each chromosome was calculated from the following relation: in the female,

$$
\begin{aligned}
\mathrm{N} / \mathrm{S}(\text { relative grain count }) & =\frac{210 \cdot 2 \times \mathrm{Gi}}{\mathrm{LG}} \\
\mathrm{S}=\frac{\mathrm{G} \times 1 / 2}{105 \cdot 1} \quad \mathrm{~N} & =\mathrm{G} / \mathrm{L}
\end{aligned}
$$

in the male,

$$
\begin{aligned}
\mathrm{N} / \mathrm{S} & =\frac{204 \cdot 2 \times \mathrm{Gi}}{\mathrm{L}(\mathrm{G}+\mathrm{Gy})} \\
\mathrm{S} & =\frac{(\mathrm{G}-\mathrm{Gy}) \times 1 / 2+\mathrm{Gy}}{102 \cdot 1}
\end{aligned}
$$

where $G$ is the grand total of grains over all 46 chromosomes in each mitotic figure, $\mathrm{L}$ is relative length (Makino and Sasaki, 1961) of each chromosome, $\mathrm{Gi}$ is the total number of grains counted over each homologous chromosome, and Gy is the number of total grains over $\mathrm{Y}$ chromosome. The relative grain count over each chromosome at the last period

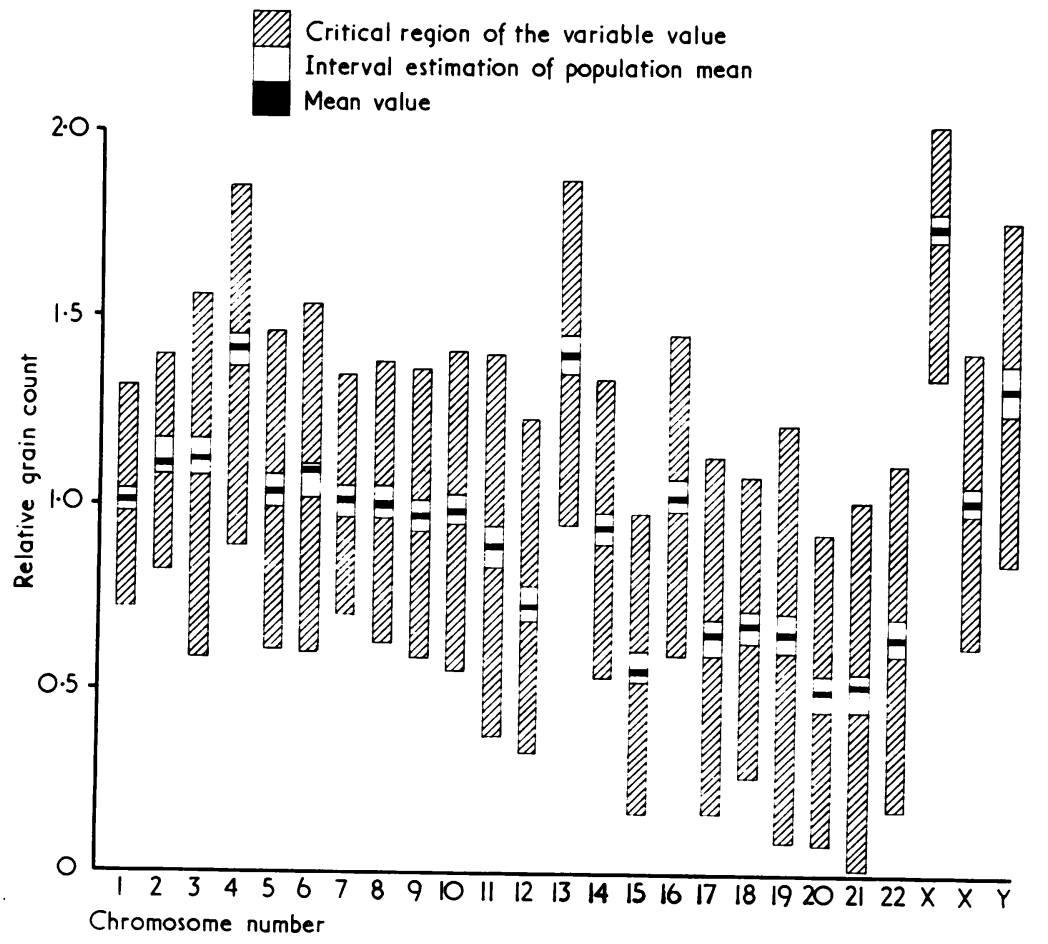

Fig. 1. Relative grain score over each chromosome. 

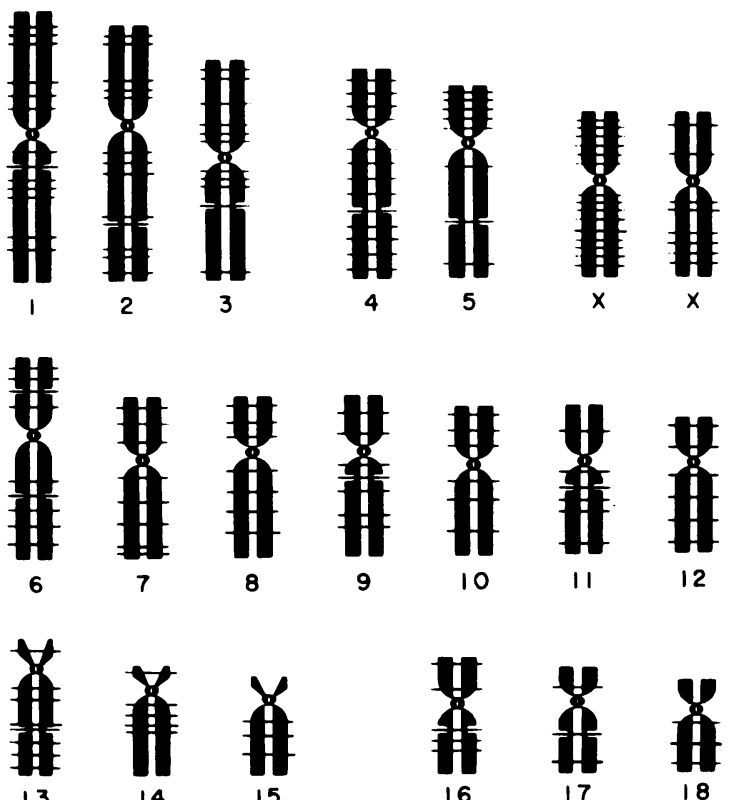

13

14

15
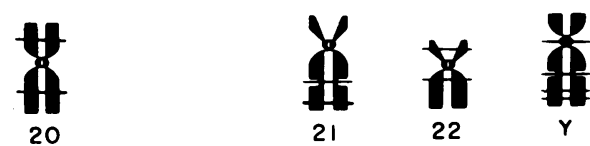

FIG. 2. Grain distribution over each chromosome (Higurashi, 1968).

of the S-phase in the cell cycle is shown in Fig. 1 (continuous labelling for five hours before harvest) (Higurashi, 1968). The grain distribution over each chromosome at the same condition is shown in Fig. 2 (Higurashi, 1968). While it was relatively easy for each chromosome of group B and D to be differentiated from both the grain distribution and the relative grain count, it was very difficult for the $\mathrm{G}$ group chromosomes to be differentiated, i.e. 21 from 22. It was, however, realized from the findings of grain distribution that 21 chromosome showed later replication over the long arm especially over the distal portion of that, and the G 22 chromosome was earlier replicating over the short arm or proximal portion of the long arms.

TABLE III

FREQUENCY AND PROPORTIONS OF TRANSLOCATED CHROMOSOMES

\begin{tabular}{c|c|c|c|c}
\hline Type of Translocation & Total & Sporadic & Inherited & Unknown \\
\hline D13/G21 & 1 & 0 & 1 & 0 \\
D14/G21 & 7 & 3 & 3 & 1 \\
D15/G21 & 0 & 0 & 0 & 0 \\
G21/G21 & 0 & 0 & 0 & 0 \\
G22/G21 & 2 & 1 & 1 & 0 \\
\hline
\end{tabular}

The frequency and proportions of the type of translocated chromosome by the labelling pattern of tritiated thymidine is shown in Table III. From these data the most frequent type in the $D / G 21$ translocation was D14/G21. Neither a D15/G21 nor a G21/G21 translocated case was seen.

\section{Discussion}

Of 321 affected children with Down's syndrome, 14 or $4.4 \%$ had a translocation. Translocations were more frequent in the younger maternal agegroup; $7 \cdot 1 \%$ of the affected children born to mothers younger than 30 years of age had a translocation-a trend also found by Wright et al. (1967). In our series, D/G21 translocations were observed more frequently than G/G21 translocation, though Wright found an approximately equal incidence. All five inherited translocations belonged to the younger maternal group, the mothers being the transmitters exclusively. If the 'unknown' four cases were added to the sporadic translocation group, there was at least a $2.9 \%$ probability that the affected child had an inherited translocation in younger maternal age-group. This agrees closely with Wright et al.'s finding that the probability is about $2 \%$ that a chromosomal study of an affected infant would reveal an inherited translocation if the mothers were under 30 years of age at parturition.

No correlation was found between the incidence of inherited translocation and paternal ages.

The labelling patterns are useful in deciphering structural rearrangements which are not recognizable morphologically, such as translocations or large inversions. Homologous chromosomes of autosome pairs show the same sequences, usually in synchrony, but sometimes slightly out of phase, in the sense that replication is sometimes more advanced in one homologue than in the other. Moreover, some attention should be paid to the assumption that the chromosome parts retain their original patterns even if structural rearrangement occurs. None the less, the method is valuable in spite of these disadvantages. From the autoradiographic analysis, D14/G21 translocations were most frequently observed in $\mathrm{D} / \mathrm{G} 21$ translocations, and two cases of G/G21 translocations were both G22/G21 translocations. The probability of the sib risk between a G21/G21 and a G22/G21 translocation carrier is theoretically different: the risk of Down's syndrome in the offspring of the former is 1 in 1 , and that of the latter is 1 in 3 . Morphological analysis cannot usually differentiate whether an extra chromosome, which is interpreted as a G/G21 translocated chromosome, is a G21/G21 
or G22/G21 translocation. For this differentiation autoradiographic analysis may be useful (German, 1964; Yunis, Hook, and Mayer, 1965).

\section{Summary}

The frequency of G21-trisomy and of translocation in Down's syndrome in Japan was evaluated. The frequency of translocation in affected children born to mothers younger than 30 years at parturition was about $7 \cdot 1 \%$ and the frequency of inherited translocation was at least $2.9 \%$ in that group. The frequency and proportions of translocated chromosome were evaluated by means of autoradiography.

We wish to thank Professor Tadao Takatsu for his advice and guidance.

\section{REFERENCES}

German, J. (1964). The pattern of DNA synthesis in the chromo somes of human blood cells. 7. Cell Biol., $20,37$.

Harnden, D. G., and Brunton, Sheila (1965). The skin cultur£ technique. In Human Chromosome Methodology, p. 57 . Ed. by J. J. Yunis. Academic Press, New York.

Higurashi, M. (1968). DNA replication pattern of human chro $\frac{9}{7}$ mosome. Acta paediat. jap., 10, 20.

—, Nakagome, Y., Nagao, T., and Matsui, I. (1967). Identifica tion of translocated chromosomes by means of autoradiography Pediatria Universitatis Tokyo, 14, 14.

Makino, S., and Sasaki, M. (1961). A study of somatic chromo.尺 somes in a Japanese population. Amer. F. hum. Genet., 13, 47.

Moorhead, P. S., Nowell, P. C., Mellman, W. J., Battips, D. M., an£ Hungerford, D. A. (1960). Chromosome preparations of leukocytes cultured from human peripheral blood. Exp. Cell Res., 20,0 613.

Wright, S. W., Day, R. W., Muller, H., and Weinhouse, R. (1967) $\overrightarrow{\vec{\omega}}$ The frequency of trisomy and translocation in Down's syndrome f. Pediat., 70, 420.

Yunis, J. J., Hook, E. B., and Mayer, M. (1965). DNA replication analysis in identifying the cytogenetic defect in Down's syndrome (mongolism). Lancet, 1, 465 . 